\title{
Transcriptional activation of macropinocytosis by the Hippo pathway following nutrient limitation
}

\author{
Sharanya Sivanand ${ }^{1}$ and Matthew G. Vander Heiden ${ }^{1,2}$ \\ ${ }^{1}$ Koch Institute for Integrative Cancer Research at Massachusetts Institute of Technology, Cambridge, Massachusetts 02139, USA; \\ ${ }^{2}$ Dana-Farber Cancer Institute, Boston, Massachusetts 02115, USA
}

Cancer cells must adapt metabolism to thrive despite nutrient limitations in the tumor microenvironment. In this issue of Genes \& Development, King and colleagues (pp. 1345-1358) report a role for transcriptional regulators of the Hippo pathway to facilitate protein scavenging and support proliferation under some nutrient-deprived conditions.

A subset of cancer cells engages in macropinocytosis to take up bulk extracellular material as a source of nutrients. Macropinocytosis appears to be particularly advantageous for tumor cells when nutrients are scarce, and cancer cells equipped with the ability to engage in protein scavenging can proliferate even when deprived of select individual amino acids (Finicle et al. 2018).

Scavenging exogenous protein can be an important source of amino acids for some cancers, including pancreatic cancer, and is attributed in part to oncogenic activation of Kras signaling (Finicle et al. 2018). Trafficking of V-ATPase to the plasma membrane downstream from oncogenic Ras is one mechanism to promote macropinocytosis (Ramirez et al. 2019); however, because Ras is not required for macropinocytosis, additional cooperative mechanisms must exist (Palm et al. 2015). Activation of PI3K downstream from Kras enhances the extent to which cancer cells can engage in macropinocytosis (Araki et al. 1996). This suggests that other means of activating $\mathrm{PI} 3 \mathrm{~K}$, as well as the metabolic context, might also determine whether cells use this process to scavenge nutrients (Michalopoulou et al. 2020). Of note, the complete pathway for how intracellular nutrient sensing influences nutrient scavenging remains unclear; furthermore, given the bidirectional feedback between nutrient availability and transcriptional responses to support growth, how each factor affects macropinocytosis is an area of ongoing investigation. King et al. (2020) have uncovered new insight into this by identifying a role for the Hippo pathway in promot-

[Keywords: Yap; cancer metabolism; macropinocytosis] Corresponding author: mvh@mit.edu Article is online at http://www.genesdev.org/cgi/doi/10.1101/gad.343632. 120. ing macropinocytosis in response to leucine limitation. Specifically, the investigators identified a role for the transcriptional coactivators Yap and Taz in activating the TEAD family of transcription factors, which promote transcriptional activation of the $A x l$ receptor tyrosine kinase that in turn activates PI3K/Akt and stimulates macropinocytosis (Fig. 1).

To identify regulators of macropinocytosis, the investigators used a panel of cell lines adapted to grow in the absence of leucine and performed chromatin accessibility studies in combination with RNA sequencing analysis to assess genome-wide changes in transcription factor occupancy and transcript levels. These studies revealed a role for the TEAD family of transcription factors as a mediator of the adaptive response to amino acid limitation. Given the known association between the Hippo pathway transcriptional coactivators Yap and Taz and the TEAD transcription factors, and the up-regulation of target genes associated with Yap activation, King et al. (2020) further investigated the role of these factors in macropinocytosis. Consistent with a role for the Hippo pathway in adaptation to leucine depletion, the investigators found enhanced nuclear enrichment of Yap/Taz, which are otherwise retained in the cytoplasm when repressed, suggesting that leucine availability affects shuttling of these factors in and out of the nucleus. While the exact link between leucine sensing and control of Yap/Taz nuclear localization is not understood, these findings suggest a cross-talk between metabolic inputs and Hippo signaling.

King et al. (2020) also found up-regulation of the Yap/ Taz transcriptional target $A x l$, which encodes a receptor tyrosine kinase that can activate the PI3K/Akt pathway, which in turn can promote macropinocytosis (Araki et al. 1996). To mechanistically test the link between Hippo pathway activation of Axl and PI3K/Akt signaling-mediated increases in macropinocytosis, the investigators used an orthogonal approach to activate Axl kinase with

(C) 2020 Sivanand and Vander Heiden This article is distributed exclusively by Cold Spring Harbor Laboratory Press for the first six months after the full-issue publication date (see http://genesdev.cshlp.org/site/misc/terms. xhtml). After six months, it is available under a Creative Commons License (Attribution-NonCommercial 4.0 International), as described at http://creativecommons.org/licenses/by-nc/4.0/. 


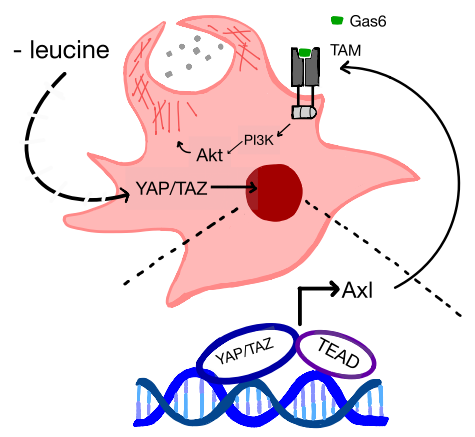

Figure 1. Transcriptional regulation of macropinocytosis. In response to leucine limitation, King et al. (2020) found that nuclear localization of Yap/Taz and transcriptional activation of the TEAD transcription factors promote increased expression of $A x l$. Activation of the TAM (Tyro3-Axl-Mertk) receptor by Gas6 facilitates PI3K/Akt signaling to promote bulk nutrient scavenging and sustain intracellular amino acid levels for growth and proliferation.

its ligand, Gas6, and confirm both increased Akt signaling and macropinocytosis induction independent of Yap/Taz activity. Together, these data support a model in which transcriptional regulation of Hippo pathway targets downstream from leucine deprivation can increase macropinocytosis via Axl-mediated activation of PI3K/Akt signaling.

Nutrient availability to cells in tumors can affect how metabolism is used to support proliferation, and which nutrients are available can vary based on both the tumor type and tissue location (Sullivan et al. 2019). How cells adapt to fluctuating nutrient levels within the tumor is less well understood, but the upstream Lats2 kinase in the Hippo signaling pathway can suppress Yap/Taz transcription and suppress tumor formation, and elevated YAP activity can cooperate with other genetic events to promote tumor growth (Han 2019). Whether these effects on cancer initiation can be explained through regulation of nutrient scavenging is unknown, but based on the findings from King et al. (2020), activation of Yap/Taz could help cells scavenge protein from their environment and adapt to nutrient-limited conditions in a developing tumor.

Prior work has also linked elevated Yap/Taz activity with epithelial-mesenchymal transition (EMT) (Cordenonsi et al. 2011), which can play a role in the capacity of cancer cells to disseminate, colonize, and proliferate in distant sites (Aiello et al. 2018). While induction of EMT is not sufficient to increase macropinocytosis, the investigators hypothesize that the response to amino acid limitation could be differentially regulated based on where cells fall within the EMT spectrum, potentially supporting a more invasive phenotype. In fact, they found cells adapted to grow in the absence of leucine are more invasive, and cells at the leading edge of the tumor display elevated Yap nuclear localization, correlating with elevated macropinocytosis.
While macropinocytosis is often considered as a source of amino acids, and protein is abundant in extracellular fluid in tissues, macropinocytosis allows scavenging of bulk extracellular material including dead cells and other macromolecules in the environment (Kim et al. 2018). This is potentially relevant for cancer cell adaption to therapy, as macropinocytosis can enable surviving cells to recycle macromolecules from dead cells in their environment. King et al. (2020) demonstrate that uptake of necrotic cells can be mediated by Gas 6 and TAM activation, hinting at additional cross-talk between nutrient sensing and extracellular signaling pathways to respond to acute stress. This discovery that the Hippo pathway facilitates nutrient scavenging in response to nutrient limitation may offer new therapeutic strategies to block nutrient uptake in some cancers.

\section{Competing interest statement}

M.G.V.H. is a consultant and scientific advisory board member for Agios Pharmaceuticals, Aglea Biotherapeutics, iTeos Therapeutics, and Auron Therapeutics.

\section{Acknowledgments}

S.S. acknowledges support from the Damon Runyon Cancer Research Foundation. M.G.V.H. acknowledges support from the Lustgarten Foundation, the Emerald Foundation, the Massachusetts Institute of Technology (MIT) Center for Precision Cancer Medicine, the Ludwig Center at MIT, a Faculty Scholars Award from the Howard Hughes Medical Institute, and the National Cancer Institute (R35CA242379 and P30CA014051).

\section{References}

Aiello NM, Maddipati R, Norgard RJ, Balli D, Li J, Yuan S, Yamazoe T, Black T, Sahmoud A, Furth EE, et al. 2018. EMT subtype influences epithelial plasticity and mode of cell migration. Dev Cell 45: 681-695.e4. doi:10.1016/j.devcel .2018 .05 .027

Araki N, Johnson MT, Swanson JA. 1996. A role for phosphoinositide 3-kinase in the completion of macropinocytosis and phagocytosis by macrophages. I Cell Biol 135: 1249-1260. doi:10.1083/jcb.135.5.1249

Cordenonsi M, Zanconato F, Azzolin L, Forcato M, Rosato A, Frasson $C$, Inui $M$, Montagner $M$, Parenti AR, Poletti A, et al. 2011. The hippo transducer TAZ confers cancer stem cell-related traits on breast cancer cells. Cell 147: 759-772. doi:10.1016/j.cell.2011.09.048

Finicle BT, Jayashankar V, Edinger AL. 2018. Nutrient scavenging in cancer. Nat Rev Cancer 18: 619-633. doi:10.1038/s41568018-0048-X

Han Y. 2019. Analysis of the role of the Hippo pathway in cancer. J Transl Med 17: 116. doi:10.1186/s12967-019-1869-4

Kim SM, Nguyen TT, Ravi A, Kubiniok P, Finicle BT, Jayashankar V, Malacrida L, Hou J, Robertson J, Gao D, et al. 2018. PTEN deficiency and AMPK activation promote nutrient scavenging and anabolism in prostate cancer cells. Cancer Discov 8: 866-883. doi:10.1158/2159-8290.CD-17-1215 
King B, Araki J, Palm W, Thompson CB. 2020. Yap/Taz promote the scavenging of extracellular nutrients through macropinocytosis. Genes Dev doi:10.1101/gad.340661.120

Michalopoulou E, Auciello FR, Bulusu V, Strachan D, Campbell $\mathrm{AD}$, Tait-Mulder J, Karim SA, Morton JP, Sansom OJ, Kamphorst JJ. 2020. Macropinocytosis renders a subset of pancreatic tumor cells resistant to mTOR inhibition. Cell Rep 30: 2729-2742.e4. doi: 10.1016/j.celrep.2020.01.080

Palm W, Park Y, Wright K, Pavlova NN, Tuveson DA, Thompson CB. 2015. The Utilization of Extracellular Proteins as Nutri- ents Is Suppressed by mTORC1. Cell 162: 259-270. doi:10 .1016/j.cell.2015.06.017

Ramirez C, Hauser AD, Vucic EA, Bar-Sagi D. 2019. Plasma membrane V-ATPase controls oncogenic RAS-induced macropinocytosis. Nature 576: 477-481. doi:10.1038/s41586-019-1831-x

Sullivan MR, Danai L V, Lewis CA, Chan SH, Gui DY, Kunchok T, Dennstedt EA, Vander Heiden MG, Muir A. 2019. Quantification of microenvironmental metabolites in murine cancers reveals determinants of tumor nutrient availability. Elife 8: e44235. doi:10.7554/eLife.44235 


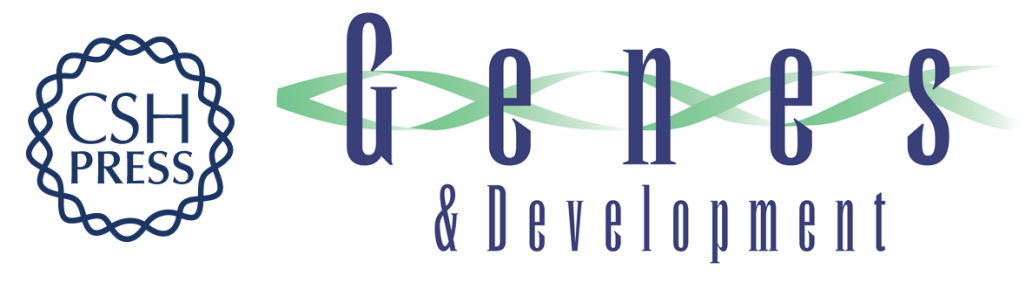

\section{Transcriptional activation of macropinocytosis by the Hippo pathway following nutrient limitation}

Sharanya Sivanand and Matthew G. Vander Heiden

Genes Dev. 2020, 34:

Access the most recent version at doi:10.1101/gad.343632.120

\section{Related Content Yap/Taz promote the scavenging of extracellular nutrients through macropinocytosis \\ Bryan King, Jingwen Araki, Wilhelm Palm, et al. \\ Genes Dev. October, 2020 34: 1345-1358}

References This article cites 11 articles, 3 of which can be accessed free at:

http://genesdev.cshlp.org/content/34/19-20/1253.full.html\#ref-list-1

Articles cited in:

http://genesdev.cshlp.org/content/34/19-20/1253.full.html\#related-urls

Creative This article is distributed exclusively by Cold Spring Harbor Laboratory Press for the first

Commons

License

six months after the full-issue publication date (see

http://genesdev.cshlp.org/site/misc/terms.xhtml). After six months, it is available under a

Creative Commons License (Attribution-NonCommercial 4.0 International), as described at http://creativecommons.org/licenses/by-nc/4.0/.

Email Alerting Receive free email alerts when new articles cite this article - sign up in the box at the top

Service right corner of the article or click here.

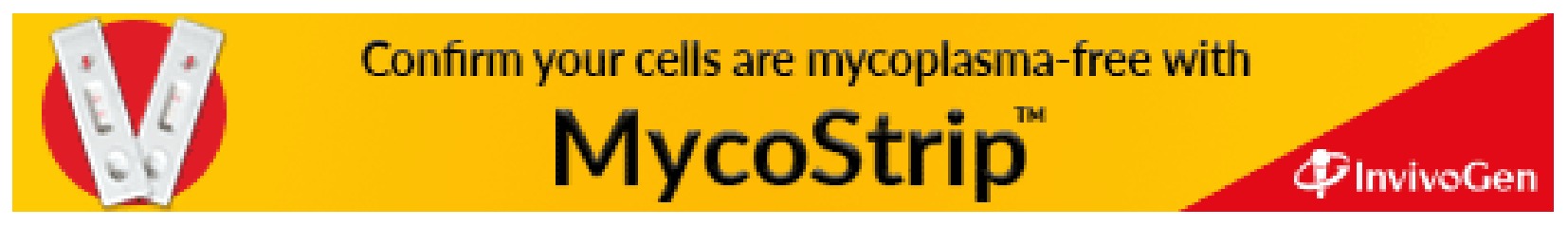

